\title{
A conversation with David Nathan
}

D avid Nathan, professor at Harvard Medical School and President Emeritus of the Dana-Farber Cancer Institute, is a renowned hematologist with contributions to the clinical treatments of $\beta$-thalassemia, sickle cell disease, and chronic granulomatous disease. Nathan (Figure 1) also contributed to the development of the first prenatal test for hematological disorders. He's known as the consummate clinical investigator, mentor, and a great wit. In the full interview, available at http://www.jci.org/kiosk/cgm, you can hear his stories about tedious Victorian poets, success in mentoring trainees, and aspiring to write like Atul Gawande.

JCI: Where did you grow up?

Nathan: Well, it was a dark and snowy night and a physician struggled to get me delivered. No, it wasn't quite like that. I've had a boring geography. My family came to Boston at the time of the Civil War and we've been there ever since. My grandfather and my father felt that travel was something that children shouldn't do, that children should go to school and do their work and be obedient and just do their thing, and that Boston was fine. And so, we stayed, and I stayed. I went to Harvard College in 1947, and I've been there ever since except for two years off for good behavior when I was at the National Cancer Institute.

JCI: The story goes that your grandfather didn't want your father to go into medical school - so how did you end up there?

Nathan: My father actually was admitted to the Harvard Medical School in 1921, but my grandfather's position on doctors was absolutely fierce. He loathed doctors. And I can still hear him saying, "They're bums and loafers. They come, they drink your coffee, and they don't do a damn thing for you." He had great respect for surgeons, but he knew his son could not be a surgeon, so he absolutely forbade it and my father went into the family business. So therefore, I became the target. As soon as I was in high school, he began to talk about my becoming a physician.

So quite naturally, when I went to Harvard, I decided I would absolutely not do

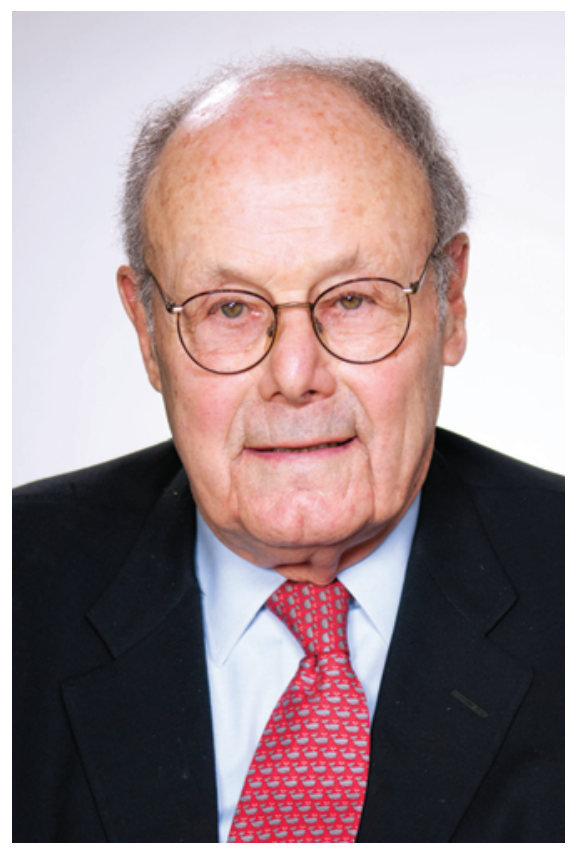

Figure 1. David Nathan on April 26, 2014. Image credit: Karen Guth.

that, that I would become an English professor, which completely outraged my poor father. He was so against that, but I had the uniform. I had the plaid jacket. I had the leather patches on my elbows. I had a pipe. I had everything, that is, but the talent. I realized, quickly, that maybe I should take chemistry the way my father said. I took all the premed courses while I still majored in English.

JCI: Did you enjoy medical school?

Nathan: I really loved the Harvard Medical School. At that time, the curriculum was really very open. One went to class a lot, but there was time, and one could explore clinical medicine and research on one's own.

I got on the ward one day, and there was a gentleman in a deep coma. I turned to the resident and asked why he was in a coma. And he said, "We really don't know. But he goes into a coma right after lunch and he stays that way for several hours. He's an alcoholic, and he has bad liver disease, and we're hearing from England that this may be related to ammonia metabolism: there's something wrong with the way these patients handle amino acids, and the amino acids create ammonia and they can't detoxify it. That's what we think, but we don't know because we can't measure ammonia." An electric light bulb went off in me when I heard that.

I went back to the biochemistry department to develop a method that would allow me to measure blood ammonia. That's what turned me into a clinical investigator. I published it, and the whole idea of being a published scientist suddenly hit me. But of course, I really wasn't a scientist. What I was, and I think I still am, is a kid in a candy store. I am absolutely fascinated by strange patients.

JCI: How did you decide to focus on hematology?

Nathan: About the last thing I wanted to do was hematology. Although Dr. [William] Castle ran the course at the Harvard Medical School and he was a great man, frankly, it was a boring course and I didn't like it.

I was married when I started medical school, and by the time I was an intern, we had two children. And it was either go to Korea in the army or go to NIH, and that was a very simple decision for me. We moved to Bethesda, and I did a year of clinical research work, learning how to do cancer trials because combination chemotherapy was just beginning at that point. I was promised that in the second year, I could do whatever research I wanted, and you have to understand that they had just built Building 10, the great clinical center, which is still there, and what a magnificent place!

I still wanted to do ammonium metabolism research. I went to see the chief of the service, then Gordon Zubrod, really a wonderful man, and I told him what I wanted to do in my second year, and he said, "Well, that's interesting, but I want you to work with Dr. Berlin, who's just arrived, to run the metabolism service. And you could do metabolism, but it may not necessarily be ammonium metabolism." I certainly wasn't going to argue with Dr. Zubrod. So I went to Dr. Berlin, and he was rocking back in his chair. He looked at me and said, "Well, now tell me something, Dr. Nathan. How many stripes would you have on your sleeve if you were in uniform?" I knew my rank and I said, “Two," and he said, "That's right! Now 
how many would I have?" And I knew that he'd come as a navy captain, that was the equivalent rank, so I said, "Four." "Good, you can actually do arithmetic; very good. That's why you're going to be a hematologist in this laboratory, starting right away."

JCI: You were ordered into hematology.

Nathan: Absolutely ordered in. I was quite angry for two days until I started doing the work. I learned a lot and I fell in love with hematology, and I've been doing it ever since.

During my senior residency, I saw my first adult with thalassemia. He was a patient with what we now know is thalassemia intermedia. He absolutely fascinated me, and I said, "That's it, I'm going to study this problem." I didn't quite realize that thalassemia intermedia might be somewhat rare and it might be difficult to see a lot of patients, but I knew that's what I wanted to do because that was a disorder that truly interested me. The other thing that I was seeing was kidney transplantation and anephric patients.

JCI: I note for the record, you have the most JCI publications of anyone that I've interviewed. There was a particular publication on your CV in 1964 that stood out to me, "Erythropoiesis in anephric man."

Nathan: Rodent and rabbit studies pinpointed the kidneys as the source of erythropoietin, but there was still a question about it. And in man, it was a real question because nobody knew. I got one patient who had been accidentally nephrectomized.

JCI: Accidentally nephrectomized?

Nathan: He was a man who had a mass in his flank and went into a community hospital where the surgeon said, "You have a mass in your flank. And I know surgery; when you have a mass, it's probably cancer, and I should take it out." So he took out this man's solitary kidney, which had, of course, hypertrophied. And there's this poor young man, now nephrectomized, and comes into the Brigham Hospital because that's where we do transplants. That's what that paper is all about: that man. There were also a couple of other patients who were nephrectomized prior to getting a transplant who had chronic renal disease. But the evidence showed very clearly that you didn't need a kidney to make erythropoietin. It was clear that the liver was a site of erythropoiesis. Now, we didn't prove that it was the liver, but there was certainly erythropoietin in that patient who had no kidneys at all.
JCI: Is it true that one of the first times you met Ed Benz, who is the current president of the Dana-Farber Cancer Institute, you made him pay for his lunch and yours?

Nathan: It is true. I did. I invited him over for lunch, but before ATMs, my wife was the person who always gave me my money for the day, and she hadn't given me any money. So poor Ed had to pay for the lunch. He hasn't forgotten that, and loves to tell the story.

One of the reasons Ed did so well was because I began to see that we needed much more technology. I was running the division at Children's, and I went over to MIT because I knew that faculty over there might be more adventurous with regard to dealing with human disease. I went to Harvey Lodish and David Baltimore's laboratory. They had a joint laboratory. It was a small space filled with brilliant people, and we started on the thalassemia problem. Ed and others were enormous beneficiaries of that. You have to be willing to change your technology, learn new methods, and that means collaboration with people who have such techniques.

JCI: You've always been an advocate for patient-oriented clinical investigation; you wrote something in the JCI about patientoriented translational clinical investigators (POTCIs). In fact, Harold Varmus asked you to lead the NIH panel on clinical research. What did you end up recommending?

Nathan: That was a great opportunity. Harold was enormously committed to it, and he really made our committee successful; he gave me a great committee - among them, Jean Wilson. What we came up with was something pretty simple, and that is, kids needed to not be in debt. When I went to Harvard Medical School, my father thought it was an outrage that the tuition was $\$ 800$. My grandson is going to medical school, and it's going to cost $\$ 50,000$ per year. This is impossible; these kids have to be debt relieved. Secondly, they need grants. They need to have a set of grants that they could get, that would give them a start.

Unfortunately, when Harold left the $\mathrm{NIH}$ director position, the next set of managers made it very complex, and now I think the Clinical Research program is too complex and too expensive, difficult to run, but that's a gripe of my own. I think we did a good job and had we just kept it going and made sure that these young people were debt free and could get grants, we'd be in better shape right now.
JCI: Over the years, you've written books and essays about particularly inspirational patients. In an essay you wrote recently, there was a phrase that was particularly indicative of your witty, eloquent, and very memorable style, and it reads, "Four decades ago, when I was a brash, 40-year-old physician, I pledged to his parents that I would not rest until he was on a course that would permit him to outlive me. In retrospect, that promise was the product of hubris or suicidal ideation."

Nathan: I wrote a book about that patient - Khaled - when he reached his 30th birthday. And now, he's in his 50s, and he's one of the most successful restaurateurs in Washington. Go to Sushiko restaurant in Chevy Chase. It's absolutely wonderful. Khaled came as this little, sick six-year-old with a hemoglobin of 1.5. There was something about that boy; I just felt he represented everything I wanted to do.

I knew I couldn't fix him the way he should be fixed. I couldn't do gene therapy, although that's coming now, but I could do something. I could fix him as best I could. I could use every technique that I had to do it. I have seen this boy respond to all of that. The book describes the field and him, and he's a symbol to me. And yes, the idea that he was going to live to his 50 s was hubris, but there he is. We did it. The advancing field did it.

JCI: You are a gifted writer. Would you ever have pursued further training in English literature or writing if you had to do it all over again?

Nathan: I would have tried, probably, but I would have never made it in English literature. And the reason I wouldn't have made it is the standards were so high. Honestly, you had to have nearly a summa cum laude performance at Harvard College to even have a chance to get into the graduate school. I think that would have been like me wanting to be the quarterback of the New England Patriots. It wasn't going to happen. I didn't have the talent.

I think I'm a good writer about medicine, but I don't think I'm a good writer in general. Dr. Castle used to say all the time, “Don't get into the ring with Joe Louis. He will beat you up. Find your own ring, find what you're good at." I think what I'm good at is seeing a patient, figuring him out, and doing something about it.

\section{Ushma S. Neill}

